\title{
Formulasi Granul Minuman Fungsional Kombinasi Ekstrak Etanol Daun Jambu Biji (Psidium guajava) dan Ekstrak Etanol Biji Klabet (Trigonella foenum-graecum)
}

\author{
Arya Eka Wardhana', Karina Citra Rani ${ }^{2}$, Aditya Trias Pradana ${ }^{2}$, dan Nikmatul Ikhrom Eka \\ Jayani $^{3}$ \\ ${ }^{1}$ Fakultas Farmasi, Universitas Surabaya, Surabaya, Indonesia \\ ${ }^{2}$ Departemen Farmasetika, Fakultas Farmasi, Universitas Surabaya, Surabaya, Indonesia \\ ${ }^{3}$ Departemen Biologi Farmasi, Fakultas Farmasi, Universitas Surabaya, Surabaya, Indonesia \\ Korespondensi: Nikmatul Ikhrom Eka Jayani \\ Email: nikmatul.ikhrom@staff.ubaya.ac.id
}

Submitted : 03-12-2021, Revised : 20-12-2021, Accepted : 22-12-2021

\begin{abstract}
ABSTRAK: Minuman fungsional diharapkan dapatmemberikan manfaatkesehatan diantaranya meningkatkan imunitas, membantu pencernaan, menurunkan kolesterol, mengandung serat tinggi, dan dapat menurunkan kadar gula. Daun jambu biji dan biji klabet berpotensi untuk dikembangkan menjadi minuman fungsinal terutama karena aktivitas antioksidannya yang tinggi. Tujuan penelitian ini adalah untuk mendapatkan formula terbaik granul minuman fungsional kombinasi ekstrak etanol daun jambu biji dengan ekstrak etanol biji klabet yang memenuhi spesifikasi dan diterima oleh panelis pada pegujian hedonik. Granul minuman fungsional dibuat dalam empat formula dengan berbagai rasio ekstrak etanol daun jambu biji dibanding ekstrak etanol biji klabet, yaitu: Formula I (3\%:0\%), Formula II (3\%:1\%), Formula III (3\%:2\%), dan Formula IV (3\%:3\%). Granul diformulasi dengan metode granulasi basah, kemudian dievaluasi karakteristik fisiknya. Hasil uji karakteristik fisik granul menunjukkan rerata kandungan lembab 1,35-1,81\%; fines 2,36-6,26\%; kecepatan alir 6,99-8,92 g/detik; sudut istirahat 31,60-34,70; indeks kompresibilitas 17,38-20,42\%; rasio Hausner 1,21-1,25. Uji hedonik menunjukkan rerata skor parameter warna $(3,32-3,76)$, bau $(3,32-4,00)$, dan rasa $(3,60-4,32)$. Formula terbaik yang memenuhi spesifikasi dan paling diterima oleh panelis pada pegujian hedonik adalah formula IV.
\end{abstract}

Kata kunci: biji klabet; daun jambu biji; granul; minuman fungsional

\begin{abstract}
Functional drinks were expected to provide health benefits including promotes immunity, digestion, lowering cholesterol, high fiber, and lowering blood sugar. Guava leaves and fenugreek seeds have the potential to be developed into functional drinks, especially because of their high antioxidant activity. The purpose of this study was to obtain the best formula for functional drink granules from the combination of guava leaf ethanolic extract and fenugreek seed ethanolic extract and which formula was accepted by the panelists in hedonic testing. The functional drink granules were made in four formulas with the ratio of guava leaf ethanolic extract compared to the fenugreek seed ethanolic extract, namely: Formula I (3\%:0\%), Formula II (3\%:1\%), Formula III (3\%:2\%), and Formula IV (3\%:3\%). The granules were formulated by the wet granulation method, then their physical characteristics were evaluated. The results of the physical characteristics test of the granules showed the average moisture content in the range between 1.351.81\%; \% fines 2.36-6.26\%; flow rate 6.99- $8.92 \mathrm{~g} / \mathrm{sec}$; angle of repose 31.60- 34.70 ; compressibility index 17.38-20.42\%; Hausner ratio 1.21-1.25. The hedonic test showed the average score of the color parameters (3.32-3.76), smell (3.32-4.00), and taste (3.60-4.32). Conclusion for this study showed that Formula IV was the best formula that meets the specifications and was most accepted by the panelists in hedonic testing.
\end{abstract}

Keywords: fenugreek; functional drinks; granule; guava leaves 


\section{Pendahuluan}

Hippocrates (460-377 SM) menyatakan bahwa "Let food be the medicine and medicine be the food" [1]. Produk minuman fungsional diharapkan dapat memberikan manfaat kesehatan yang diinginkan, nyaman, dengan kemasan modern dan harga yang terjangkau [2]. Ada banyak herbal yang berpotensi untuk dikembangkan menjadi minuman fungsional, diantaranya adalah Psidium guajava (jambu biji) dan Trigonella foenumgraecum (klabet). Psidium guajava (Famili Myrtaceae) secara tradisional, bagian daunnya banyak digunakan mengatasi beberapa gangguan, seperti rematik, diare, diabetes mellitus, anti hiperlipidemia, batuk, dan sariawan [3, 4]. Kandungan senyawa yang ada pada daun jambu biji diantaranya senyawa fenolik dan flavonoid. Zat aktif utama dalam daun jambu biji adalah asam galat, asam caffeic, guaijaverin, tanin, karotenoid, dan triterpenoid [5]. Adanya polifenol dikaitkan dengan efek antioksidan dan dapat bertindak sebagai imunostimulan yang dapat menyebabkan peningkatan sistem kekebalan tubuh [6].

Trigonella foenum-graecum (Famili Fabaceae), bagian bijinya dikaitkan dengan beberapa efek farmakologis seperti anti-diabetes, anti-kolesterol, gastroprotektif, karminatif, anti-kanker, antioksidan, pencahar, stimulasi nafsu makan, dan stimulasi laktasi pada wanita setelah melahirkan [7]. Biji klabet mengandung $\mathrm{Ca}, \mathrm{P}, \mathrm{Fe}, \mathrm{Na}$, dan $\mathrm{K}$, serta karbohidrat, vitamin (karoten, tiamin, riboflavin, asam nikotinat, asam folat, dll) juga asam amino [8]. Selain itu, biji klabet juga mengandung senyawa steroid, alkaloid (piridin, trigonelin), polifenol, flavonoid (luteolin, apigenin, quercetin) dan senyawa volatile [9]. Efek farmakologis sebagai anti-diabet dan penurun kolesterol paling banyak dilaporkan dan telah ada hasil systematic review yang menunjukkan efek positif pada beberapa uji randomized clinical trial (RCT) [10].

Berdasarkan latar belakang di atas maka ekstrak daun jambu biji dikombinasikan dengan ekstrak biji klabet. Kombinasi lebih dari satu herbal tersebut memungkinkan terjadinya efek saling melengkapi satu sama lain (sinergisme) sehingga diharapkan dapat menghasilkan efek farmakologis yang menguntungkan [11]. Ekstrak daun jambu biji dan biji klabet selanjutnya diformulasi menjadi granul minuman fungsional. Sediaan granul relatif lebih praktis, stabil terhadap lembab, dan mudah untuk dikonsumsi [12]. Formulasi granul dengan bahan aktif ekstrak tanaman telah banyak dilaporkan, diantara-nya penelitian Juliantoni (2013) yang membuat granul ekstrak daun jambu biji yang kemudian dikempa menjadi tablet [13], dan penelitian Bangu (2018) terkait pembuatan granul effervescent dari ekstrak etanol daun jambu biji [14]. Tujuan penelitian ini adalah untuk mendapatkan formula terbaik granul minuman fungsional ekstrak daun jambu biji dengan ekstrak biji klabet yang memenuhi spesifikasi dan paling diterima oleh panelis pada pegujian hedonik.

\section{Bahan dan metode}

\subsection{Bahan kimia}

Bahan dalam penelitian ini diantaranya pemanis stevia f.g (PT. Jamu Iboe, Indonesia), etanol 96\% p.g (PT. Brataco, Indonesia), maltodekstrin p.g (Shandong, China), primogel p.g (PT. Brataco, Indonesia), tween 80 p.g (PT. Brataco, Indonesia), Avicel ${ }^{\circledR}$ pH 101 p.g (PT. Brataco, Indonesia), Na benzoat f.g (PT. Brataco, Indonesia), sukrosa f.g (PT. Brataco, Indonesia), flavour jeruk f.g (KH Roberts, Indonesia) dan aqua demineralisata p.g (PT. Brataco, Indonesia).

\subsection{Bahan tanaman}

Daun jambu biji (Psidium guajava L.) didapatkan dari Surabaya, Jawa Timur yang telah dipanen pada bulan Januari 2019 dan telah dideterminasi pada Pusat Informasi dan Pengembangan Obat Tradisional (PIPOT) Universitas Surabaya dengan surat determinasi No. 1397/D.T/IV/2019. Biji klabet (Trigonella foenum-graecum) didapatkan dari Batu, Jawa 
Timur yang telah dipanen pada bulan Januari 2019 dan dideterminasi di Laboratorium Herbal Materia Medica Batu dengan surat determinasi No. 074/233A/102.7/2019.

\subsection{Alat}

Alat yang digunakan dalam penelitian diantaranya: oven (Memmert), Waterbath (Memmert), pengayak (No. 10, 16, 20, 30, 50, 6080 dan 100), blender (Phillips), Rotary Evaporator (Buchi), timbangan analitik (Ohaus Pioneer $^{\mathrm{TM}}$ ), Moisture Analyzer (Mettler Toledo), alat pengetuk (Tapping Machine) (ERWEKA), retsch vibrator (D-42759 HAAN), corong standar, pH meter (Schott Handylab 11), stopwatch, pinset, viskometer VT-04 (Rion), kertas perkamen, kertas saring Whatman no. 4, dan alat alat-alat gelas laboratorium (Pyrex).

\subsection{Preparasi ekstrak}

Ekstraksi daun jambu biji dan biji klabet dilakukan secara terpisah. Masing-masing simplisia diekstraksi dengan metode maserasi selama 3x24 jam. Rasio antara simplisia dengan pelarut (etanol 70\%) adalah 1:5. Ekstrak selanjutnya disaring dengan menggunakan kertas saring Whatman no. 4 dan dipekatkan dengan Rotary Evaporator pada suhu $50^{\circ} \mathrm{C}$ selama 3 jam, dilanjutkan dengan waterbath suhu $50^{\circ} \mathrm{C}$ sampai didapatkan ekstrak kental [15]

\subsection{Preparasi granul minuman fungsional}

Pada penelitian ini dibuat empat formula granul minuman fungsional dengan bahan aktif kombinasi ekstrak jambu biji dan ekstrak biji klabet. Keempat formula tersebut dapat dilihat pada Tabel 1. Granul minuman fungsional dibuat dengan metode granulasi basah. Masing-masing ekstrak kental daun jambu biji dan ekstrak kental biji klabet dicampur dengan tween 80. Serbuk daun stevia, primogel, maltodekstrin, sukrosa, natrium benzoat, flavour jeruk, dan Avicel $^{\circledR}$ ditimbang sesuai kebutuhan. Setengah bagian Avice ${ }^{\circledR}$ dimasukkan ke dalam wadah pencampur untuk mengeringkan campuran ekstrak daun jambu biji dengan ekstrak biji klabet. Setelah kering, dimasukkan serbuk daun stevia, primogel, natrium benzoat dalam wadah pencampur, dan diaduk sampai campuran homogen. Maltodextrin, sukrosa, dan Avicel ${ }^{\circledR}$ dicampur secara bertahap dengan bahan-bahan yang ada di dalam wadah pencampur, campuran diaduk sampai homogen. Selanjutnya, aquadem ditambahkan sampai terbentuk massa granul dengan konsistensi yang diinginkan. Massa granul kemudian diayak dengan menggunakan ayakan mesh 10. Granul dikeringkan dalam almari pengering pada suhu $55-60^{\circ} \mathrm{C}$ selama 6 jam. Granul kering diayak kembali dengan menggunakan ayakan mesh 16. Granul yang didapat dilakukan pengujian pada karakteristik fisik dan uji hedonik pada konsumen.

\subsection{Pengujian karakteristik fisik sediaan \\ 2.6.1. Kandungan lembab}

Sebanyak 5 g granul ditimbang dan dimasukkan pada alat moisture content balance, granul diratakan permukaannya. Kandungan lembab dinyatakan sebagai \% MC (moisture content) [16].

\subsubsection{Distribusi ukuran partikel}

Pengayak dengan mesh 20, 30, 50, 60 80, dan 100 serta pan penampung disusun secara berurutan dari atas ke bawah. Granul ditimbang sebanyak $100 \mathrm{~g}$ dan dimasukkan pada pengayak paling atas (mesh 20). Serangkaian pengayak digetarkan dengan "Resch vibrator" selama 20 menit dengan kecepatan $60 \mathrm{rpm}$. Ditimbang bobot granul yang tertinggal pada masing-masing pengayak dan dibuat tabel serta kurva distribusi ukuran granul [17].

\subsubsection{Sifat alir}

\subsubsection{Kecepatan alir}

Corong diletakkan pada statif dengan jarak ujung pipa corong 10,0 $\pm 0,2 \mathrm{~cm}$ dari bidang datar. Granul ditimbang sebanyak $100 \mathrm{~g}$ dan dituangkan pada corong dengan dasar lubang corong ditutup 
Tabel 1. Formula granul minuman fungsional kombinasi ekstrak daun jambu biji dan ekstrak biji klabet

\begin{tabular}{lllll}
\hline Komposisi & Formula I & Formula II & Formula III & Formula IV \\
\hline $\begin{array}{l}\text { Ekstrak etanol } \\
\text { daun jambu biji (\%) }\end{array}$ & 3 & 3 & 3 & 3 \\
$\begin{array}{l}\text { Ekstrak etanol } \\
\text { biji klabet (\%) }\end{array}$ & 0 & 1 & 2 & 3 \\
\hline Stevia (\%) & 0,50 & 0,50 & 0,50 & 0,50 \\
\hline Maltodextrin (\%) & 7 & 7 & 7 & 7 \\
\hline Primogel (\%) & 4 & 4 & 4 & 4 \\
\hline Tween 80 (\%) & 0,50 & 0,50 & 0,50 & 0,50 \\
\hline Na Benzoat (\%) & 0,20 & 0,20 & 0,20 & 0,20 \\
\hline Sukrosa (\%) & 75 & 75 & 75 & 75 \\
\hline Flavour jeruk (\%) & 1 & 1 & 1 & 1 \\
\hline Aqua purificata (ml) & 2 & 2 & 2 & 2 \\
\hline Avicel ${ }^{\circledR}$ (ad g) & Ad 30 & Ad 30 & Ad 30 & Ad 30 \\
\hline
\end{tabular}

terlebih dahulu. Selanjutnya, dicatat waktu yang diperlukan mulai dari granul mengalir sampai semua granul pada corong habis [18].

\subsubsection{Sudut istirahat}

Pada uji kecepatan alir, granul yang turun dari corong akan membentuk timbunan berbentuk kerucut. Selanjutnya dihitung sudut istirahat ( $\mathrm{Tg}$

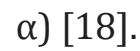

\subsubsection{Bobot jenis}

\subsubsection{Bobot jenis nyata}

Granul ditimbang sebanyak 40 g dan dituangkan melalui corong ke dalam gelas ukur $100 \mathrm{ml}$ yang diposisikan miring dengan sudut $45^{\circ}$. Selanjutnya gelas ukur ditegakkan dan digoyangkan dengan cepat untuk meratakan permukaan bahan. Volume akhir ( $\mathrm{ml}$ ) dibaca dan dihitung bobot jenis nyata ( $\rho$ ) [18].

\subsubsection{Bobot jenis mampat}

Granul dalam gelas ukur hasil pengukuran bobot jenis nyata diletakkan pada meja dengan alas matras. Volume granul pada gelas ukur diukur pada tiap interval 100 ketukan dari 100500 ketukan. Pengamatan dilakukan sampai volume tetap/konstan pada tiga kali pengamatan. Selanjutnya dihitung bobot jenis mampat $(\rho)$ [18].

\subsubsection{Indeks kompresibilitas}

Indeks kompresibilitas merupakan kemampuan serbuk untuk dapat dimampatkan [12].

\subsubsection{Rasio hausner}

Rasio Hausner merupakan perbandingan antara bobot jenis mampat dengan bobot jenis nyata [12].

\subsubsection{Pengujian setelah granul direkonstitusi}

\subsubsection{Pengukuran $\mathrm{pH}$ sediaan}

Granul ditimbang sebanyak $5 \mathrm{~g}$ dan dilarutkan pada $50 \mathrm{ml}$ air. $\mathrm{pH}$ diukur pada suhu ruang dengan $\mathrm{pH}$ meter (Schott Handylab 11) yang telah dikalibrasi sebelumnya [19].

\subsubsection{Uji viskositas}

Pengukuran viskositas dilakukan pada sampel dengan berat \pm 30 gram yang dilarutkan pada air $400 \mathrm{ml}$ menggunakan viskometer VT-04 [20]

\subsection{Uji hedonik}

Uji hedonik yang dilakukan mengacu pada SNI Petunjuk Pengujian Organoleptik dan atau Sensori 01-2346-2006 [21]. Untuk menilai masing-masing sampel, panelis mendapatkan form uji hedonik yang berisi skala penilaian 
mulai satu sampai dengan lima. Skala (1) sangat tidak suka, (2) tidak suka, (3) netral, (4) suka dan (5) sangat suka. Hasil evaluasi pada uji hedonik selanjutnya ditabulasi untuk menggolongkan tingkat kesukaan panelis terhadap formula granul minuman fungsional. Skor penerimaan panelis dianalisa secara statistika dengan uji KruskalWallis [20].

\section{Hasil dan diskusi}

Pada penelitian ini dilakukan formulasi granul dengan bahan aktif ekstrak etanol daun jambu biji yang dikombinasikan dengan ekstrak etanol biji klabet dengan metode granulasi basah. Bentuk sediaan granul dipilih karena memiliki beberapa keuntungan dibandingkan dengan serbuk, diantaranya: granul mengalir lebih baik daripada serbuk, stabilitas granul lebih baik, membuat campuran lebih homogen, memperbaiki karakteristik pengempaan bahan aktif dan memiliki luas permukaan yang lebih kecil sehingga lebih tahan terhadap pengaruh udara [22]. Pada penelitian ini, aqua purificata digunakan sebagai pembasah, untuk membentuk massa basah atau membentuk granul. Granul yang lembab kemudian dikeringkan dan diayak untuk mendapatkan ukuran granul yang sesuai dan seragam. Cairan yang ditambahkan mengikat serbuk yang lembab membentu ikatan kuat selama proses pengeringan melalui pembentukan aglomerat [23].

Komposisi bahan tambahan yang digunakan dalam membuat granul, yaitu daun stevia sebagai pemanis, primogel sebagai superdesintegran, tween 80 sebagai surfaktan, natrium benzoat sebagai pengawet, flavour jeruk sebagai perasa, maltodekstrin sebagai pengikat, Avicel ${ }^{\circledR} \mathrm{pH} 101$ sebagai pengering, dan sukrosa sebagai pengisi. Evaluasi karakteristik granul yang terbentuk diperlukan untuk menentukan formula mana yang paling baik. Evaluasi organoleptis dilakukan dengan mengamati bentuk, warna, bau, dan rasa granul. Hasil uji menunjukkan keempat formula memenuhi spesifikasi sediaan yaitu memiliki bentuk granul dengan warna krem, bau jeruk dan berasa manis (Gambar 1 dan Tabel 2). Pada formula tidak ditambahkan pewarna sehingga warna granul dipengaruhi warna kedua ekstrak yang awalnya berwarna coklat. Pemilihan flavour jeruk disesuaikan dengan hasil granulasi yang cenderung berwarna krem jingga. Rasa manis dipengaruhi oleh penggunaan sukrosa, stevia dan maltodextrin.

Evaluasi karakteristik fisik granul minuman fungsional dilakukan pada beberapa parameter uji, diantaranya kandungan lembab, \% fines, laju alir, sudut istirahat, indeks kompresibilitas, dan rasio Hausner. Hasil evaluasi karakteristik fisik granul dapat dilihat pada Tabel 3. Hasil uji kandungan lembab untuk keempat formula granul tidak memenuhi persyaratan. Rerata kandungan lembab untuk F I, F II, F III, dan F IV berturutturut $1,35 \pm 0,56 \% ; 1,37 \pm 0,38 \% ; 1,47 \pm 0,44 \%$; dan $1,81 \pm 0,03 \%$. Syarat kandungan lembab pada granul adalah 2-4\% [24]. Kandungan lembab di bawah $2 \%$ menyebabkan granul cenderung rapuh. Hasil ini mungkin terjadi karena penambahan cairan granulasi tidak optimal dan proses pengeringan yang terlalu lama [25]. Sebaliknya, kadar lembab yang terlalu tinggi akan menjadi katalisator bagi reaksi kimia serta mempercepat tumbuhnya mikroba. Kadar lembab yang tinggi juga akan meningkatkan higroskopisitas granul yang dapat mengganggu stabilitas dari sediaan granul [26].

Pada evaluasi distribusi ukuran partikel, keempat formula granul memiliki distribusi ukuran partikel yang memenuhi persyaratan. Rerata \% fines untuk F I, F II, F III, dan F IV berturutturut 2,36 $\pm 1,12 \% ; 3,00 \pm 0,00 \% ; 4,51 \pm 0,40 \%$ dan $6,26 \pm 0,87 \%$. Persen fines untuk keempat formula masuk rentang spesifikasi, yaitu $\leq 10 \%$ [24]. Persen fines yang rendah menunjukkan bahwa granul memilki sifat alir yang baik. Semakin kecil ukuran partikel menyebabkan semakin besar luas permukaan sehingga gaya kohesi dan adhesi makin besar mengakibatkan sifat alir yang buruk [27]. Sifat alir granul dapat diketahui dengan pengujian kecepatan alir dan sudut istirahat granul. Pengujian sifat alir granul sangat penting 

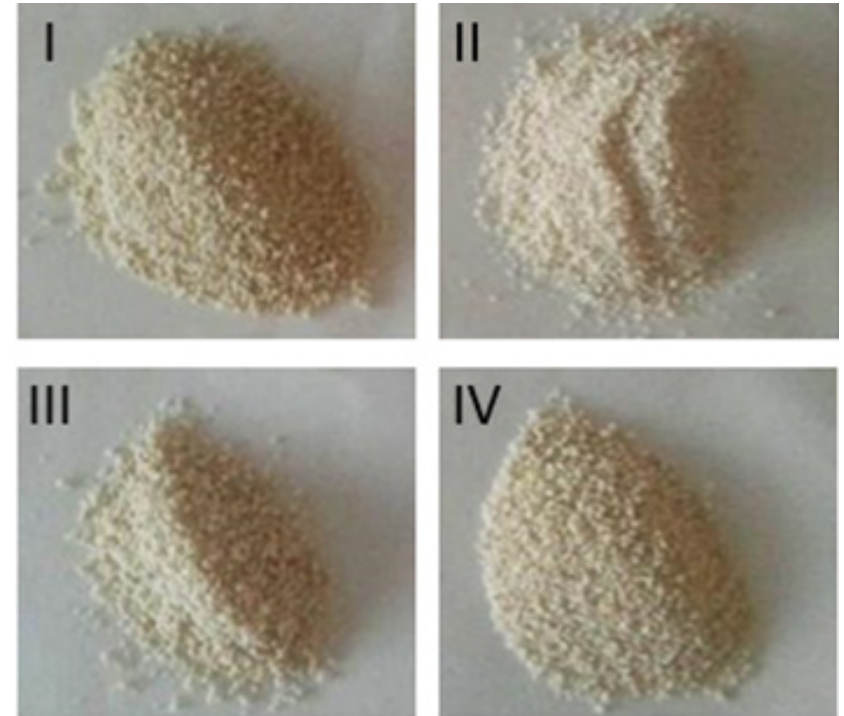

Gambar 1. Granul kombinasi ekstrak daun jambu biji dan ekstrak biji klabet: I. F I (3\%:0\%); II. F II (3\%:1\%); III. F III (3\%:2\%); dan IV. F IV (3\%:3\%)

Tabel 2. Organoleptis granul minuman fungsional kombinasi ekstrak daun jambu biji dan ekstrak biji klabet

\begin{tabular}{llllll}
\hline Parameter Uji & Formula I & Formula II & Formula III & Formula IV & Spesifikasi \\
\hline Warna & Krem & Krem & Krem & Krem & Krem \\
Bau & Jeruk & Jeruk & Jeruk & Jeruk & Jeruk \\
Rasa & Manis & Manis & Manis & Manis & Manis \\
Bentuk & Granul & Granul & Granul & Granul & Granul \\
\hline
\end{tabular}

Tabel 3. Karakteristik fisik granul minuman fungsional kombinasi ekstrak daun jambu biji dan ekstrak biji klabet

\begin{tabular}{llllll}
\hline Parameter Uji & Formula I & Formula II & Formula III & Formula IV & Spesifikasi \\
\hline MC (\%) & $1,35 \pm 0,56$ & $1,37 \pm 0,38$ & $1,47 \pm 0,44$ & $1,81 \pm 0,03$ & $2-4[24]$ \\
Fines (\%) & $2,36 \pm 1,12$ & $3,00 \pm 0,00$ & $4,51 \pm 0,45$ & $6,26 \pm 0,87$ & $\leq 10[24]$ \\
Kecepatan alir (g/detik) & $6,99 \pm 0,28$ & $7,62 \pm 0,03$ & $8,18 \pm 0,73$ & $8,92 \pm 0,42$ & $4-10[28]$ \\
Sudut istirahat ( $\left.{ }^{\circ}\right)$ & $31,6 \pm 0,0$ & $32,7 \pm 0,0$ & $33,9 \pm 0,0$ & $34,7 \pm 0,0$ & $30-40[18]$ \\
Indeks kompresibilitas (\%) & $17,38 \pm 2,01$ & $17,62 \pm 1,31$ & $17,80 \pm 1,85$ & $20,42 \pm 2,52$ & $10-20[18]$ \\
Rasio Hausner & $1,21 \pm 0,02$ & $1,21 \pm 0,03$ & $1,22 \pm 0,02$ & $1,25 \pm 0,04$ & $1,00-1,25[18]$ \\
\hline
\end{tabular}

untuk dilakukan karena berperan penting dalam homogenitas dosis pada saat pengemasan granul [22]. Rerata kecepatan alir untuk F I, F II, F III dan F IV berturut-turut 6,99 $\pm 0,28 \mathrm{~g} /$ detik; 7,62 $\pm 0,03 \mathrm{~g} /$ detik; 8,18 $\pm 0,73 \mathrm{~g} /$ detik; dan 8,92 $\pm 0,42 \mathrm{~g} /$ detik. Hasil evaluasi kecepatan alir granul keempat formula memenuhi spesifikasi [28]. Kecepatan alir granul antara 4-10 g/detik tergolong granul dapat mengalir dengan baik/ mudah mengalir [26]. Sifat alir granul juga ditentukan oleh sudut istirahat [18].

Hasil evaluasi rerata sudut istirahat untuk F I, F II, F III dan F IV berturut-turut yaitu $31,60 \pm 0,00^{\circ}$; $32,70 \pm 0,00^{\circ} ; 33,90 \pm 0,00^{\circ}$; dan $34,70 \pm 0,00^{\circ}$. Hasil evaluasi sudut istirahat granul, keempat formula memiliki sifat alir yang baik, yaitu $31-35^{\circ}[29$, 30]. Pada formulasi granul minuman fungsional kombinasi ekstrak daun jambu biji dan ekstrak biji klabet digunakan Avicel ${ }^{\circledR}$ sebagai pengering. Penggunaan Avicel ${ }^{\circledR}$ dapat menghasilkan butiran 
dengan karakteristik aliran yang baik karena mendorong kohesi partikel serbuk. Avice ${ }^{\circledR}$ dapat bertindak sebagai pengikat yang menggabungkan partikel menjadi aglomerat dan penghancur. Avice ${ }^{\circledR}$ juga memiliki sifat kompresibilitas yang baik sehingga dapat menghasilkan butiran dengan ukuran yang sama [31].

Indeks kompresibilitas yang baik berada pada rentang 5-25\% dan rasio Hausner sebesar 1,00-1,25 menunjukkan sifat alir yang baik pada granul. Berdasarkan hasil pengujian, indeks kompresibilitas (\%) dan rasio Hausner dari semua formula sesuai dengan persyaratan, menunjukkan bahwa semua granul yang dihasilkan memiliki aliran dan kompresibilitas yang sangat baik. Distribusi ukuran partikel yang homogen dan bentuk partikel sferis berperan penting dalam mempengaruhi kemampuan alir granul. Pada pengujian indeks kompresibilitas keempat formula memenuhi spesifikasi, yaitu 10-20 \%. Hasil uji rerata indeks kompresibilitas untuk F I, F II, F III, dan F IV berturut-turut yaitu: $17,38 \pm 2,01 \% ; 17,62 \pm 1,31 \% ; 17,80 \pm 1,85 \%$ dan $20,42 \pm 2,52 \%$. Sedangkan hasil evaluasi rasio Hausner menunjukkan bahwa keempat formula memenuhi spesifikasi, yaitu 1,00-1,25. Hasil uji rerata rasio Hausner untuk F I, F II, F III, dan F IV berturut-turut yaitu: $1,21 \pm 0,02 ; 1,21 \pm 0,03$; $1,22 \pm 0,02$; dan $1,25 \pm 0,04$.

Granul yang terbentuk juga dilakukan pengujian setelah direkonstitusi dengan air. Uji yang dilakukan meliputi pengukuran $\mathrm{pH}$ dan viskositas sediaan. pH minuman fungsional yang disarankan adalah berkisar antara 6-7. Apabila $\mathrm{pH}$ minuman terlalu asam dikhawatirkan dapat mengiritasi lambung, jika terlalu basa maka rasa minuman menjadi pahit [20]. Pada penelitian dihasilkan $\mathrm{pH}$ untuk keempat formula memenuhi spesifikasi yang ditentukan. Hasil uji rerata pH untuk F I, F II, F III, dan F IV berturut-turut yaitu $6,729 \pm 0,005 ; 6,730 \pm 0,006 ; 6,733 \pm 0,004$; dan $6,734 \pm 0,007$. Uji viskositas dilakukan untuk mengukur kekentalan sediaan granul setelah direkonstitusi. Viskositas dapat mempengaruhi cita rasa minuman fungsional. Jika terlalu encer, akan meninggalkan after taste yang bertahan lebih lama dan jika terlalu kental, minuman akan sulit ditelan [20]. Uji viskositas pada keempat formula menunjukkan nilai viskositas yang memenuhi spesifikasi. Hasil uji rerata viskositas untuk F I, F II, F III, dan F IV berturut-turut yaitu $36,67 \pm 2,89$; $38,33 \pm 2,89 ; 38,33 \pm 2,89$ dan $46,67 \pm 5,77$.

Uji hedonik dilakukan pada keempat formula granul minuman fungsional ekstrak daun jambu biji dan biji klabet. Uji hedonik dilakukan untuk mengevaluasi penerimaan panelis terhadap sediaan granul minuman fungsional setelah direkonstitusi. Gambar 2 menunjukkan bahwa F IV (garis kuning) lebih dekat dengan skor penerimaan 5 (pilihan sangat suka) untuk parameter warna, bau, dan rasa. Tabel 5 menunjukkan hasil rerata skor (mean rank) dari parameter warna, bau, dan rasa. Nilai mean rank parameter warna adalah 3,32-3,76 (pilihan netral sampai suka), parameter bau berkisar antara 3,32-4,00 (pilihan netral sampai suka), dan parameter rasa antara 3,60-4,32 (pilihan netral sampai suka).

Hasil analisis statistik dengan metode Kruskal wallis pada tingkat kepercayaan 95\% terhadap skor parameter warna, bau, dan rasa menunjukkan bahwa terdapat perbedaan bermakna $(p<0,05)$ respon panelis dari keempat formula tersebut. Granul minuman fungsional ekstrak daun jambu biji dan biji klabet formula IV merupakan formula yang paling diminati oleh panelis ditinjau dari parameter warna, bau, dan rasa. Hal ini ditunjukkan dari nilai mean rank formula IV yang paling tinggi diantara keempat formula granul tersebut (Tabel 5). Berdasarkan analisis karakteristik granul dan hasil uji hedonik diketahui bahwa formula IV merupakan kandidat formula yang dapat dikembangkan lebih lanjut. Hal ini disebabkan formula tersebut mampu menghasilkan granul dengan ukuran yang seragam, kemampuan alir yang cukup baik, viskositas yang memadai untuk produk minuman fungsional, dan paling diminati oleh panelis. 


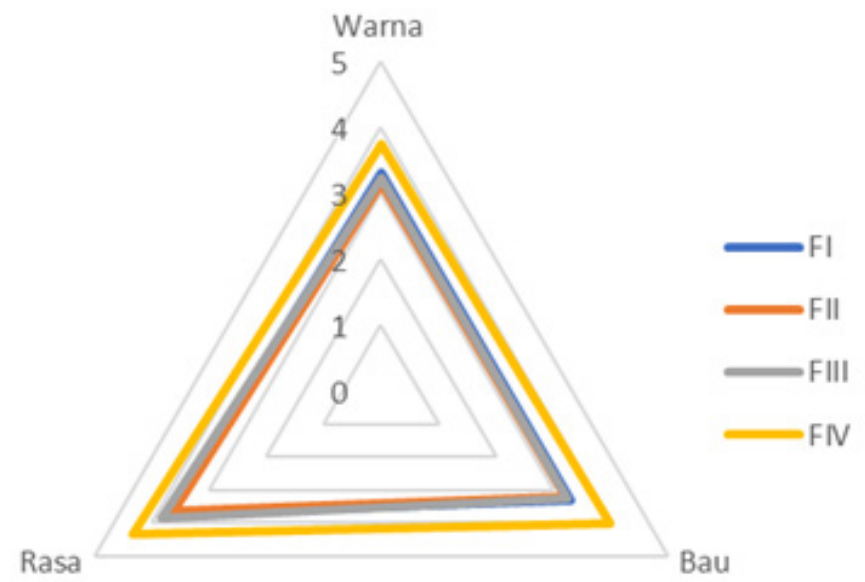

Gambar 2. Mean rank skor evaluasi penerimaan panelis terhadap granul kombinasi ekstrak daun jambu biji dan ekstrak biji klabet ditinjau dari parameter warna, bau, dan rasa

Tabel 4. Karakteristik fisik granul minuman fungsional kombinasi ekstrak daun jambu biji dan ekstrak biji klabet setelah direkonstitusi

\begin{tabular}{llllll}
\hline Parameter Uji & Formula I & Formula II & Formula III & Formula IV & Spesifikasi \\
\hline $\mathrm{pH}$ & $6,729 \pm 0,005$ & $6,730 \pm 0,006$ & $6,733 \pm 0,004$ & $6,734 \pm 0,007$ & $6-7[14]$ \\
Viskositas (cPs) & $36,67 \pm 2,89$ & $38,33 \pm 2,89$ & $38,33 \pm 2,89$ & $46,67 \pm 5,77$ & $40,00-50,00[20]$ \\
\hline
\end{tabular}

Tabel 5. Nilai rerata dari skor tingkat kesukaan panelis terhadap granul minuman fungsional kombinasi ekstrak daun jambu biji dan ekstrak biji klabet

\begin{tabular}{lllll}
\hline Indikator & Formula I & Formula II & Formula III & Formula IV \\
\hline Warna & 3,32 & 3,16 & 3,24 & 3,76 \\
Bau & 3,32 & 3,2 & 3,24 & 4 \\
Rasa & 3,72 & 3,6 & 3,84 & 4,32 \\
\hline
\end{tabular}

\section{Kesimpulan}

Formula terbaik granul minuman fungsional ekstrak daun jambu biji dengan biji klabet yang memenuhi spesifikasi dan paling diterima oleh panelis pada pegujian hedonik adalah formula IV.

\section{Ucapan Terima Kasih}

Ucapan terima kasih pada Fakultas Farmasi Universitas Surabaya dan Lembaga Penelitian dan Pengabdian Masyarakat (LPPM) Universitas Surabaya, Indonesia.

\section{Daftar Pustaka}

1. Corbo MR, Bevilacqua A, Petruzzi L, Casanova FP, Sinigaglia M. Functional Beverages: The Emerging Side of Functional Foods: Commercial Trends, Research, and Health Implications. Compr Rev Food Sci Food Saf. 2014;13:1192-206.

2. Nazir M, Arif S, Khan RS, Nazir W, Khalid N. Opportunities and challenges for functional and medicinal beverages: Current and future trends. Trends Food Sci Technol. 2019;88:513-26.

3. Mazumdar S, Akter R, Talukder D. Antidiabetic and antidiarrhoeal effects on ethanolic extract of Psidium guajava (L.) Bat. Leaves in Wister rats. Asian Pac J Trop Biomed. 2015;5:10-4.

4. Díaz-de-Cerio E, Verardo V, Gómez-Caravaca AM, Fernandez-Gutierrez A, Segura-Carretero A. 
Health effects of Psidium guajava L. Leaves: An overview of the last decade. International Journal of Molecular Sciences. 2017;18 1-31.

5. Seo J, Lee S, Elam ML, Johnson SA, Kang J, Arjmandi BH. Study to find the best extraction solvent for use with guava leaves ( Psidium guajava L.) for high antioxidant efficacy. Food Sci Nutr. 2014;2:174-80.

6. Laily N, Kusumaningtyas RW, Sukarti I, Rini MRDK. The Potency of Guava Psidium Guajava (L.) Leaves as a Functional Immunostimulatory Ingredient. Procedia Chem. 2015;14:301-7.

7. Mahbub J, Mou RA, Sikta SA, Rahman A, Dash PR. Biological and Medicinal Significance of Trigonella foenum-graecum: a review. Int J Life Sci Rev. 2018;4:15-26.

8. Gupta S, Gupta P, Patsariya S. Phytochemical and Pharmacological review on Fenugreek (Trigonella foenum-graecum) Antidiabetic activity. Current Research in Pharmaceutical Sciences. 2012;11-3.

9. Goyal S, Gupta N, Chatterjee S. Investigating Therapeutic Potential of Trigonella foenumgraecum L . as Our Defense Mechanism against Several Human Diseases. Journal of Toxicology. 2016.

10. Roberts KT. Review The Potential of Fenugreek (Trigonella foenum-graecum) as a Functional Food and Nutraceutical and Its Effects on Glycemia and Lipidemia. Journal of Medicinal Food. 2011;14:1485-9.

11. Suvarna R, Shenoy RP, Hadapad BS, Nayak AV. Journal of Ayurveda and Integrative Medicine Effectiveness of polyherbal formulations for the treatment of type 2 Diabetes mellitus - A systematic review and meta-analysis. J Ayurveda Integr Med. 2021;12:213-22.

12. Husni P, Fadhiilah ML, Hasanah U. Formulasi Dan Uji Stabilitas Fisik Granul Instan Serbuk Kering Tangkai Genjer (Limnocharis flava (L.) Buchenau.) Sebagai Suplemen Penambah Serat. $J$ Ilm Farm Farmasyifa 2020;3:1-8.

13. Juliantoni Y, Mufrod. Formulation Lazonge of Guava Leaves (Psidium guava L.) Containing Flavonoids With A Combination Of Excipients Mannitol - Sucrose. Tradit Med J. 2013;18:103-8.
14. Bangu AI. Formulasi dan Evaluasi Granul Effervescent Ekstrak Etanol Daun Jambu Biji ( Psidium guajava L.). Karya Tulis Ilmiah. Politeknik Kesehatan KEMENKES Kupang. 2018.

15. Abeed Al Mashkor IM. Phenolic content and antioxidant activity of fenugreek seeds extract. Int J Pharmacogn Phytochem Res. 2014;6:841-4.

16. Nawatila R, Putri RA, Nabilla A, Oktaviani FL, Efendi RN, Anjarsari AAK, Tanuwijaya CD, Pradana AT. Pengembangan Granul Herbal Kumis Kucing, Temulawak, dan Pegagan dengan Pengisi Maltodextrine dan Spray Dried Lactose. Media Pharmaceutica Indonesiana. 2020; 3(1):1-9.

17. Yulia R, Pradana AT, Sie SS, Suri FA. Formulation and physical characteristics of detam ii soybean (Glycine max (L.) merr) tablet with various concentration of silicon dioxide and magnesium stearate. Asian J Pharm Clin Res. 2018;11:283-8.

18. York P, Aulton M, Marriott C, John F, David A, John P, James W, Graham B, John S, Andrew T, Marianne A, John C, Chris M, Michael B. Pharmaceutics: The Science of Dosage Form Design. 2001;197-210, 137-138.

19. Rahmawati IF, Pribadi P, Hidayat IW. Formulasi dan evaluasi granul effervescent ekstrak daun binahong (Anredera cordifolia (Tenore) Steen.). Pharmaciana. 2016;6(2):139-48.

20. Rani KC, Parfati N, Muarofah D, Sacharia SN. Formulasi Granul Effervescent Herba Meniran (Phyllanthus niruri L.) dengan Variasi Suspending Agent Xanthan Gum, CMC-Na, dan Kombinasi CMC-Na-Mikrokristalin Selulosa RC- 591. J Sains Farm Klin. 2020;7:39.

21. SNI. Petunjuk Pengujian Organoleptik dan atau Sensori 01-2346-2006. BSN (Badan Standarisasi Nasional) 2006; 2-14.

22. Allen L V, Ansel HC. Ansel's Pharmaceutical Dosage Forms and Drug Delivery Systems. 2014.

23. Agrawal R, Naveen Y. Pharmaceutical Processing - A Review on Wet Granulation Technology. Int J Pharm Front Res. 2011;1:65-83.

24. Lachman L. Teori dan Praktek Farmasi Industri. Universitas Indonesia, 1994.

25. Alyami H, Koner J, Dahmash EZ, Bowen J, Terry 
D, Afzal RM. Microparticle surface layering through dry coating: impact of moisture content and process parameters on the properties of orally disintegrating tablets. J Pharm Pharmacol. 2017;69:807-22.

26. Zaidan S, Djamil R, Supriyono, Nuraini S. Karakterisasi Sediaan Granul Biji Sirsak (Annona muricata L.) dan Uji Efektivitas terhadap Larva Aedes aegypti L. sebagai Kandidat Biolarvasida. Ilmu Kefarmasian Indonesia. 2016;14:256-62.

27. Etti CJ, Yusof YA, Chin NL, Mohd Tahir S. Effects of formulation on flowability of selected herbal powders using compendial methods and powder flow analyser. International Food Research Journal. 2016;23 (suppl):225-30.

28. Carlin BAC. Direct Compression and the Role of Filler-binders. In: Augsburger LL, Hoag SW (eds) Pharmaceutical Dosage Forms: tablets Third Edition Volume 2: Rational Design and Formulation. New York: Informa Healthcare USA, 2008, pp. 173-216.

29. Šimek M, Grünwaldová V, Kratochvíl B. Comparison of compression and material properties of differently shaped and sized paracetamols. KONA Powder Part J. 2017; 34:197-206.

30. Saad Suliman R, Ali HS, Elhaj BMA, Suliman R. A Recent Progresses and Manufacturing Techniques in Pharmaceutical Powders and Granulation. International Journal of Pharmaceutical and Clinical Research. 2019;11(1):1-12.

31. Hadi M, Diyah Ikasari E. Optimasi Suhu Dan Waktu Pengeringan Granul Tablet Kunyah Bee Pollen. Majalah Farmaseutik. 2014;10(1):176-81. 